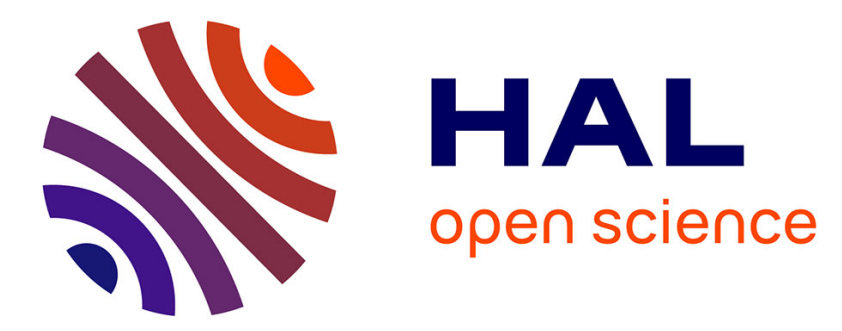

\title{
A Numerical Study of the Ductile Tearing in Welded Joints Using the Rice-Tracey Void Growth Model
}

\author{
A. Al Rassis, A. Imad, M. Nait Abdelaziz, G. Mesmacque, A. Amrouche, C. \\ Eripret
}

\section{- To cite this version:}

A. Al Rassis, A. Imad, M. Nait Abdelaziz, G. Mesmacque, A. Amrouche, et al.. A Numerical Study of the Ductile Tearing in Welded Joints Using the Rice-Tracey Void Growth Model. Journal de Physique IV Proceedings, 1996, 06 (C6), pp.C6-13-C6-21. 10.1051/jp4:1996602 . jpa-00254430

\section{HAL Id: jpa-00254430 https://hal.science/jpa-00254430}

Submitted on 1 Jan 1996

HAL is a multi-disciplinary open access archive for the deposit and dissemination of scientific research documents, whether they are published or not. The documents may come from teaching and research institutions in France or abroad, or from public or private research centers.
L'archive ouverte pluridisciplinaire $\mathbf{H A L}$, est destinée au dépôt et à la diffusion de documents scientifiques de niveau recherche, publiés ou non, émanant des établissements d'enseignement et de recherche français ou étrangers, des laboratoires publics ou privés. 


\title{
A Numerical Study of the Ductile Tearing in Welded Joints Using the Rice-Tracey Void Growth Model
}

\author{
A. Al Rassis*,**, A. Imad*, M. Nait Abdelaziz**, G. Mesmacque**, A. Amrouche** and C. Eripret*** \\ * Laboratoire d'Etudes des Structures, Ecole HEI, 13 rue de Toul, 59046 Lille cedex, France \\ ** Laboratoire de Mécanique de Lille, URA 1441 du CNRS, BP. 179, 59653 Villeneuve d'Ascq cedex, \\ France \\ *** Direction des Etudes et Recherches, Département M.T.C., EDF Centre Les Renardières, BP. 1, \\ 77250 Moret-sur-Loing, France
}

\begin{abstract}
A finite element (FE) analysis of a CT25 specimen has been achieved for three configurations of a welded structure : monometallic (base metal), bimetallic (base metal and weld metal) and trimetallic (BM+WM+HAZ). Using the RICE-TRACEY model, a void growth parameter $R / R_{0}$ has been computed for each case. The evolution of this parameter indicates clearly that the bimetallic specimen is the most harmful while the monometallic case leads to conservative results. Furthermore, a crack propagation analysis, based upon a critical value of the void growth rate, has been performed. Numerical and experimental tearing rates $\mathrm{dJ} / \mathrm{da}$ are in good agreement but numerical $\mathrm{J}$ values are clearly underestimated. Concerning the trimetallic specimen, when analysing the void growth rate distribution around the crack tip, a prediction of crack propagation direction may be possible.
\end{abstract}

\section{INTRODUCTION}

The ductile tearing of welded joints is generally described using global approaches of elastic-plastic fracture mechanics and many results are available in the literature in terms of fracture parameters such as J-integral, CTOD or charpy V-energy [1-3]. Because a welded joint exhibits both a macro-heterogeneity (base metal BM, weld metal WM and heat affected zone HAZ) and micro-heterogeneity (coarse-grain and fine-grain HAZ), the ductile tearing study of such components is complex and the question about the validity of a global approach clearly arises $[2,3,10,11]$.

The ductile tearing proceeds from the physical mechanisms of nucleation, growth and coalescence of microcracks or microvoids. As the growth phase is essentially considered as the predominant part in the ductile fracture process, many theoretical models have been developed to predict the void growth rate [48] and the developement of numerical tools allows their improvement. Therefore, the local approach constitutes an alternative and/or a complementary axis of investigation.

Precisely, the analysis of the deformation of a single spherical void in an infinite rigid-plastic medium has led RICE and TRACEY [5] to point out the exponential influence of the stress triaxiality ratio on the void growth rate parameter. According to these authors, the parameter is expressed as : 


$$
\mathrm{d}\left(\operatorname{Ln} \frac{\mathrm{R}}{\mathrm{R}_{0}}\right)=0.283 \exp \left[1.5 \frac{\sigma_{\mathrm{m}}}{\sigma_{\mathrm{eq}}}\right] \mathrm{d} \varepsilon_{\mathrm{cq}}
$$

where:

$-\mathbf{R}_{0}$ : initial radius of the void.

- $\mathbf{R}$ : actual radius of the void.

$-\sigma_{\mathfrak{m}}: \quad$ hydrostatic stress.

$-\sigma_{\mathrm{eq}}$ : equivalent Von-Mises stress.

$-d \varepsilon_{e q}$ : increment of plastic deformation.

The determination of the critical value of $R / R_{0}$ corresponding to crack initiation requies both experimental measures (critical strain value) and a finite element analysis which provides the stress and strain distribution around the crack tip.

The general purpose of this study is to examine the sensitivity of such an approach when dealing with fracture of welded joints in which mis-matched strengths are involved. More precisely, it seems important to analyse the effect of the HAZ on the local properties of a welded structure.

Using the F.E.M., a numerical investigation has been achieved and three different configurations of a CT25 specimen have been examined (fig. 1):

- monometallic (base metal , BM)

- bimetallic (BM + weld metal,$W M)$

- trimetallic ( BM + WM + heat affected zone, HAZ)

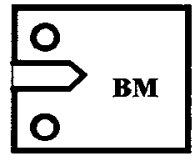

monometallic

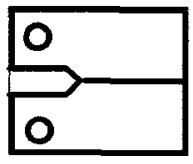

Bimetallic

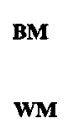

$\mathbf{W M}$

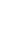

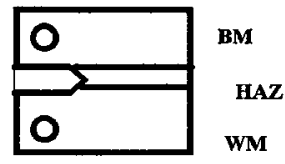

Trimetallic

Figure 1 : The different configurations of the CT25 specimen

\section{MATERIALS}

The weld metal and the base metal are respectively a 316L and a Z3 CN $20-09 \mathrm{M}$ stainless steels. Their chemical composition is given by table 1 .

The mechanical behaviour of each component ( $\mathrm{BM}, \mathrm{WM}, \mathrm{HAZ}$ ) is described using the RambergOsgood power law :

$$
\sigma=\sigma_{y}+k \varepsilon_{p}^{n}
$$

where :

$-\varepsilon_{\mathbf{p}}:$ plastic strain

- $\sigma_{\mathrm{y}}:$ yield stress

- $n$ and $k$ are constants of the material. 
The values of $\sigma_{\mathrm{y}}, \mathrm{n}$ and $\mathrm{k}$ are presented in table 2 . For the base metal and the weld metal, these values are issued from experimental tensile tests performed at a temperature of $673 \mathrm{~K}$, while for the HAZ they have been approximated in the following way:

- the room temperature yield stress has been evaluated from hardness measures. Its value at $673 \mathrm{~K}$ is determined using an extrapolation formula.

$-\mathrm{n}$ and $\mathrm{k}$ have been arbitrarly taken equal to those of the WM.

For each material, the evolution of true stress as a function of the true strain is shown in fig. 2 . Elastic constants $\mathrm{E}$ and $v$ are respectively $176.10^{3} \mathrm{MPa}$ and 0.3 .

$\begin{array}{lccccccccccc} & \text { C } & \text { S } & \text { P } & \text { Si } & \text { Mn } & \text { Ni } & \text { Cr } & \text { Mo } & \text { Cu } & \text { N } & \text { O } \\ \text { Base Metal } & 0.015 & 0.003 & 0.022 & 1.15 & 1.01 & 9.74 & 20.01 & 0.39 & 0.125 & 0.081 & 0.006 \\ \text { Weld Metal } & 0.008 & 0.011 & 0.018 & 0.51 & 1.19 & 12.7 & 19.2 & 2.6 & 0.137 & 0.051 & 0.007\end{array}$

Table 1 : Chemical composition of the stainless steels (\%weight).

$\begin{array}{cccc} & \text { BM } & \text { HAZ } & \text { WM } \\ \mathrm{k}(\mathrm{MPa}) & 1066.9 & 324.58 & 324.58 \\ \mathbf{n} & 0.826 & 0.206 & 0.206 \\ \sigma_{y}(\mathrm{MPa}) & 133 & 220 & 320\end{array}$

Table 2 : Values of the parameters of the RAMBERG-OSGOOD law.

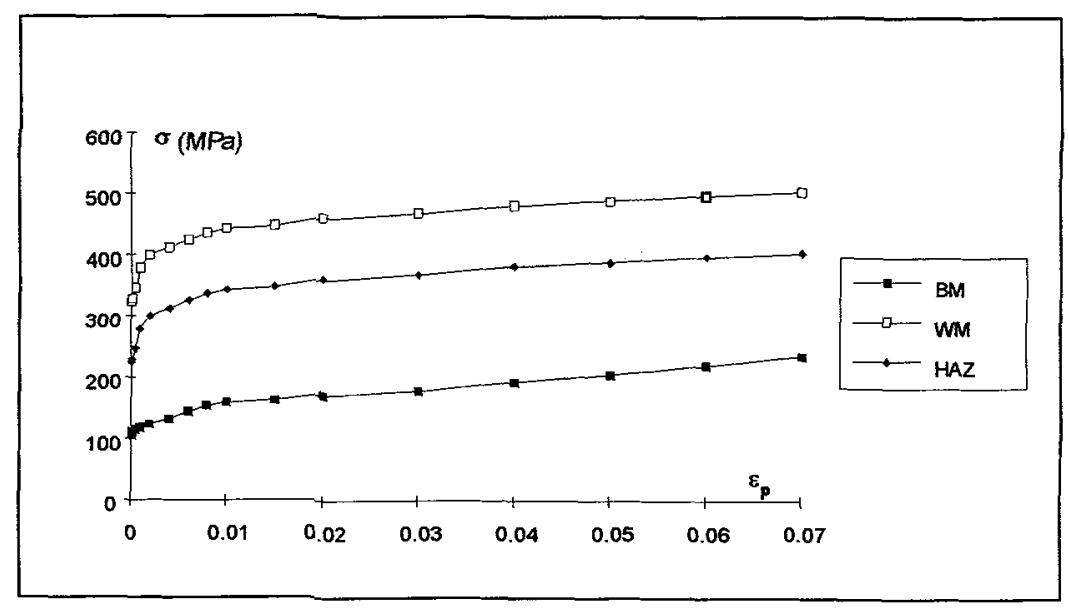

Figure 2 : True stress as a function of true-plastic strain 
The specimen which has been modelled is a standard CT of $25 \mathrm{~mm}$ thickness ,50 mm width and with a a/W ratio of 0.63 .

\section{NUMERICAL STUDY}

The SYSTUS [9] finite element program has been used. Large strains, plane strain situation and isotropic hardening with a Von Mises rule have been assumed in the calculations. The finite element modelling incorporates the eight-noded isoparametric element ( six nodes for triangles).

The meshing consists of fine square mesh around the crack tip $(0.2 \mathrm{~mm} \mathrm{x} 0.2 \mathrm{~mm})$ and relatively coarse mesh near the boundary. Because of symmetry, only one half of the specimen was modelled in the case of the monometallic configuration. The typical discretization consisted of 1954 nodal points and 618 elements. Concerning the case of the heterogeneous material (bimetallic and trimetallic configurations), the whole specimen has to be analysed. This meshing contains 1236 elements and 3857 nodes.

The crack is situated in the HAZ, about $1 \mathrm{~mm}$ from the melting line (the width of the HAZ is taken equal to $3 \mathrm{~mm}$ ), while it was assigned to the interface for the bimetallic specimen. The specimen loading is applied, step by step, in terms of assigned displacement.

\section{RESULTS AND DISCUSSIONS}

According to the literature $[4,6,7]$, for a given element, the void growth parameter $R / R o$ is computed, using the average values of stresses and strains. Considering the trimetallic specimen, the values of this parameter corresponding to two adjacent elements on both sides of the crack tip ( as shown in fig. 3b ) are plotted versus the displacement (fig. 3a). The results clearly show that this parameter increases more rapidly in the element laying to the B.M side. Consequently, this parameter has been determined in the above-mentionned element and the corresponding results are shown, for each case, in fig. 4 .

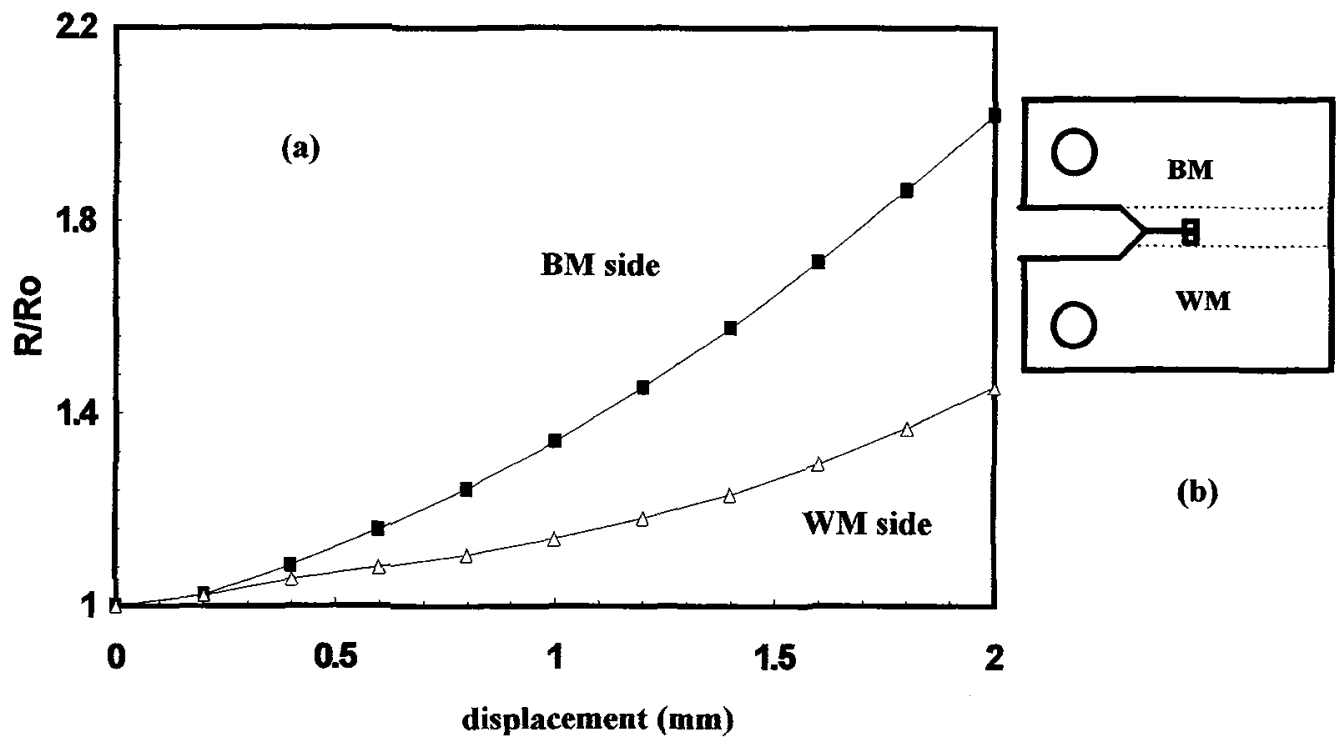

Figure 3 : evolution of R/R0 vs displacement. 
The void growth parameter is very sensitive to the stress and strain distribution as confirmed by the significant difference observed in the evolution of R/Ro. As shown in fig. 5, a plot of this parameter as a function of the J-integral lead to a similar conclusion.

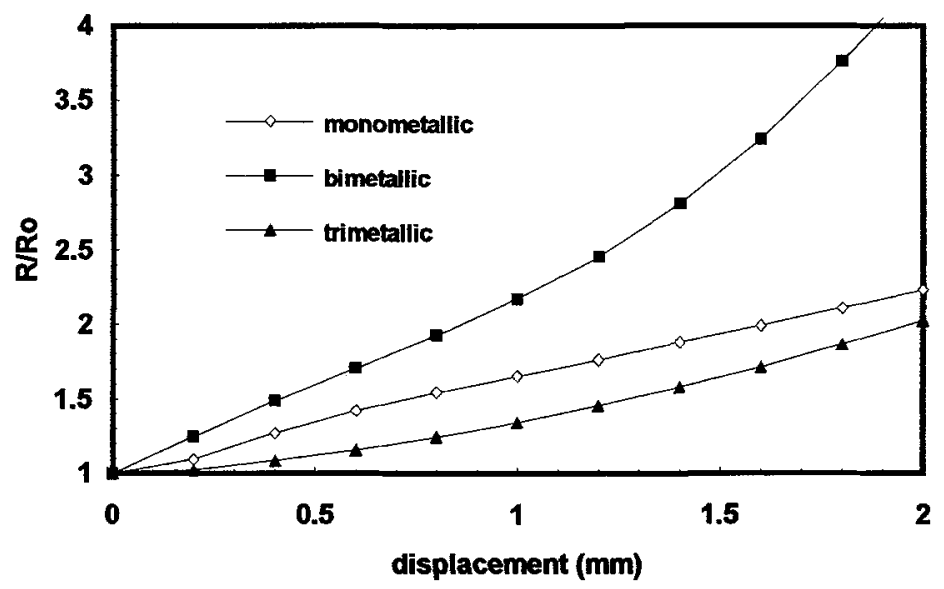

Figure 4 : the void growth parameter vs displacement

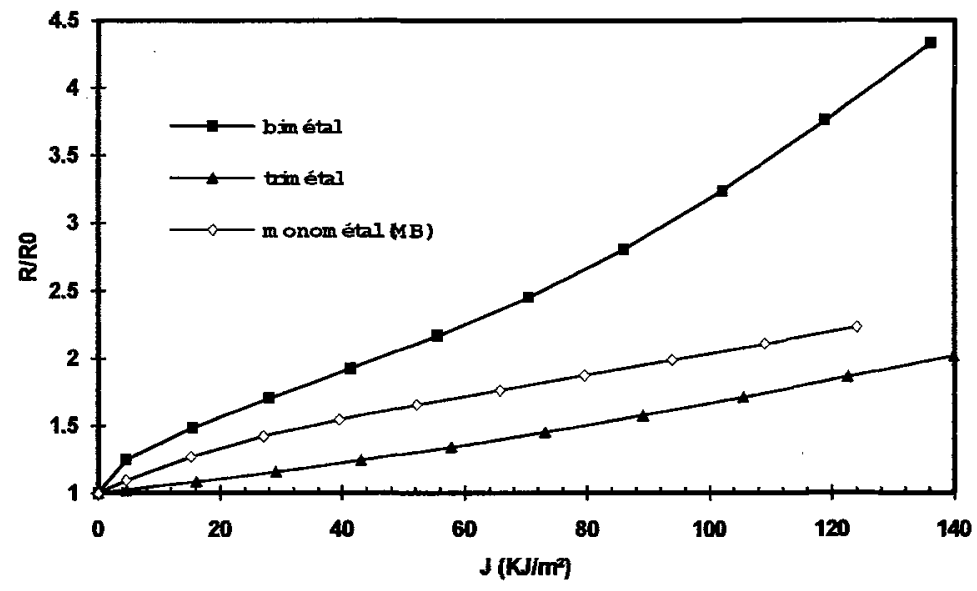

Figure 5 : R/R0 vs energy parameter $\mathrm{J}$.

These results suggest the following comments :

- The bimetallic specimen gives the highest values of the $R / R_{0}$ parameter, indicating that the configuration is really dangerous when over-matching is involved. In this case, the crack is laying at the interface BMWM and the yielding process is essentially developping in the BM side.

- Figure 4 also illustrates the benefical effects of the $\mathrm{HAZ}$ when considering the trimetallic specimen. In this case, the $R / R_{0}$ data constitutes a lower limit because it is computed in the HAZ the yield stress of wich is approximatively twice the BM yield stress. 
Therefore, adopting the softer material's properties to characterize fracture of over-matched welded joints seems to be a conservative approach.

\section{CRACK PROPAGATION}

\subsection{Ductile crack extension}

In order to improve the validity of a propagation criterion based upon a critical value of the void growth parameter, a numerical analysis of crack propagation in the case of the monometallic configuration (base metal) has been performed. The critical load corresponding to crack initiation has been determined using experimental results of a fracture test on a CT25 specimen. As shown in figure (5-a) value is corresponding to the change of slope in the load-crack extension curve. The F.E. analysis of the same specimen gives the evolution of the void growth rate as a function of the applied load, in the first element in front of the crack tip and consequently allow the determination of the (R/R $\left.\mathbf{R}_{0}\right)_{\mathrm{c}}$ value (fig.5-b).

Assuming that the crack propagates in the plane of the initial notch, the F.E. analysis has been achieved using a node release (NR) technique $[7,8,12]$. The crack is increased by an amount of $\Delta \mathrm{a}=0.2 \mathrm{~mm}$ (corresponding to the element size around the crack tip) by releasing the nodes of the first element in front of the crack tip when $\left(R / R_{0}\right)_{c}$ is reached in this element. Increasing the load, the same operation is carried out again until reaching the crack propagation instability.

A comparison of experimental and numerical results is given in figure 6 , in which $\mathrm{J}$ is plotted versus crack extension $\Delta \mathrm{a}$. The energy parameter $\mathrm{J}$ is here determined using the ASTM formula [15].

Experimental and numerical estimation of the tearing rate $\mathrm{dJ} / \mathrm{da}$ are in good agreement but for a given $\Delta \mathrm{a}$ numerical values of $\mathrm{J}$ are clearly underestimated. This divergence may be the consequence of :

- Firstly, the degree of uncertainty on the critical value of the void growth parameter.

- Secondly, it is obvious that the element size of the meshing plays an important role in the crack propagation simulation. It seems that the values we have assigned here are too large since for a constant $\mathrm{J}$, the crack extension $\Delta \mathrm{a}$, which is directly equal to the element length, is overestimated.

- Thirdly, the F.E. analysis has been achieved under the assumption that crack propagates in its initial plane. A deviation of the crack, which is often observed experimentally, involves an increase of the energy parameter $J$. This may be an explanation of the numerical underestimation of this parameter.

\subsection{Prediction of crack propagation direction}

The distribution of the void growth parameter around the crack tip is given in table 3 for the trimetallic specimen.

Assuming that crack initiation is governed by a critical value $\left(R / R_{0}\right)_{c}$, the results summarized in fig.7, suggest that the crack propagation will be deviated towards the $B M$. 


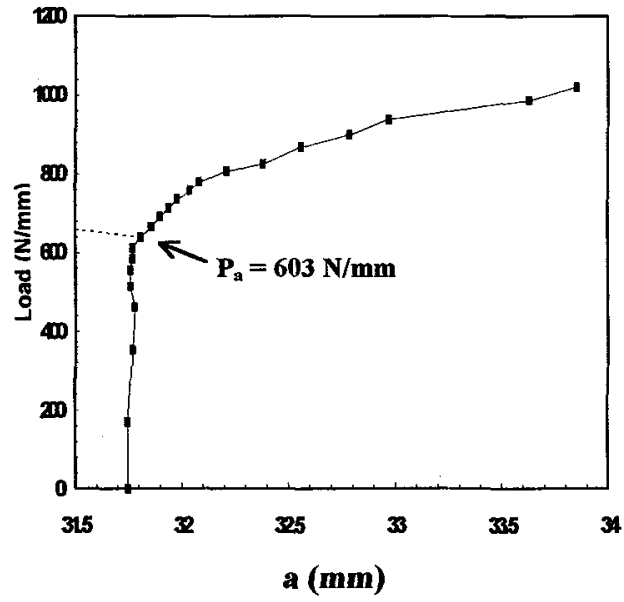

(a) load vs crack length (experimental)

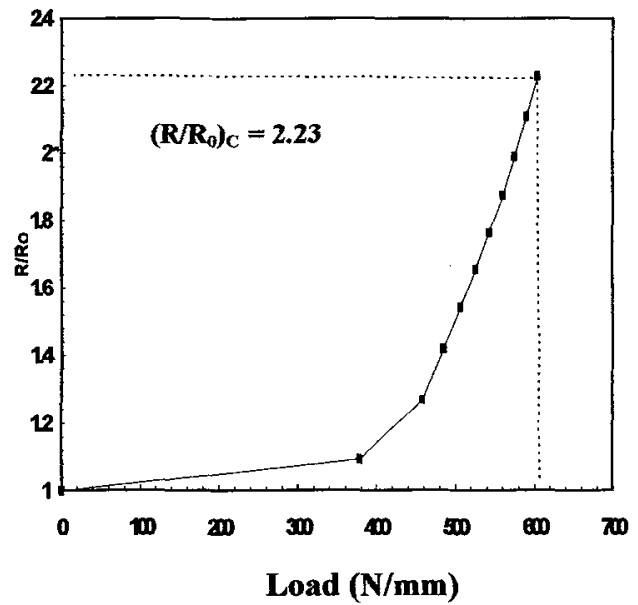

(b) R/Ro vs load (numerical)

Figure 5 : determination of $\left(R / R_{0}\right)_{c}$ value.

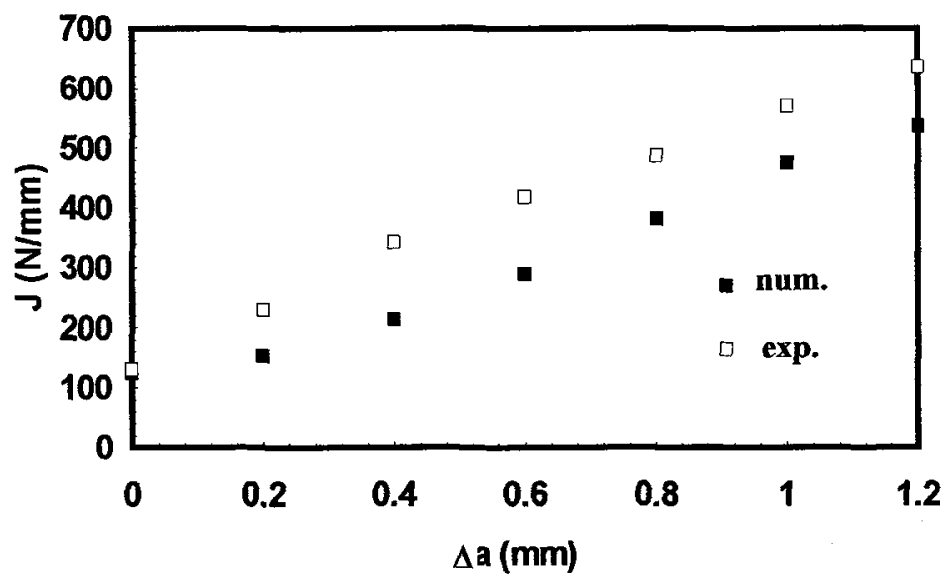

Figure 6 : energy parameter J vs crack extension

Such a result is of particular interest because it illustrates the possibility to predict the direction of crack propagation when analysing the $R / R_{0}$ distribution, provided that $\left(R / R_{0}\right)_{c}$ is an intrinsic property of a given material. 


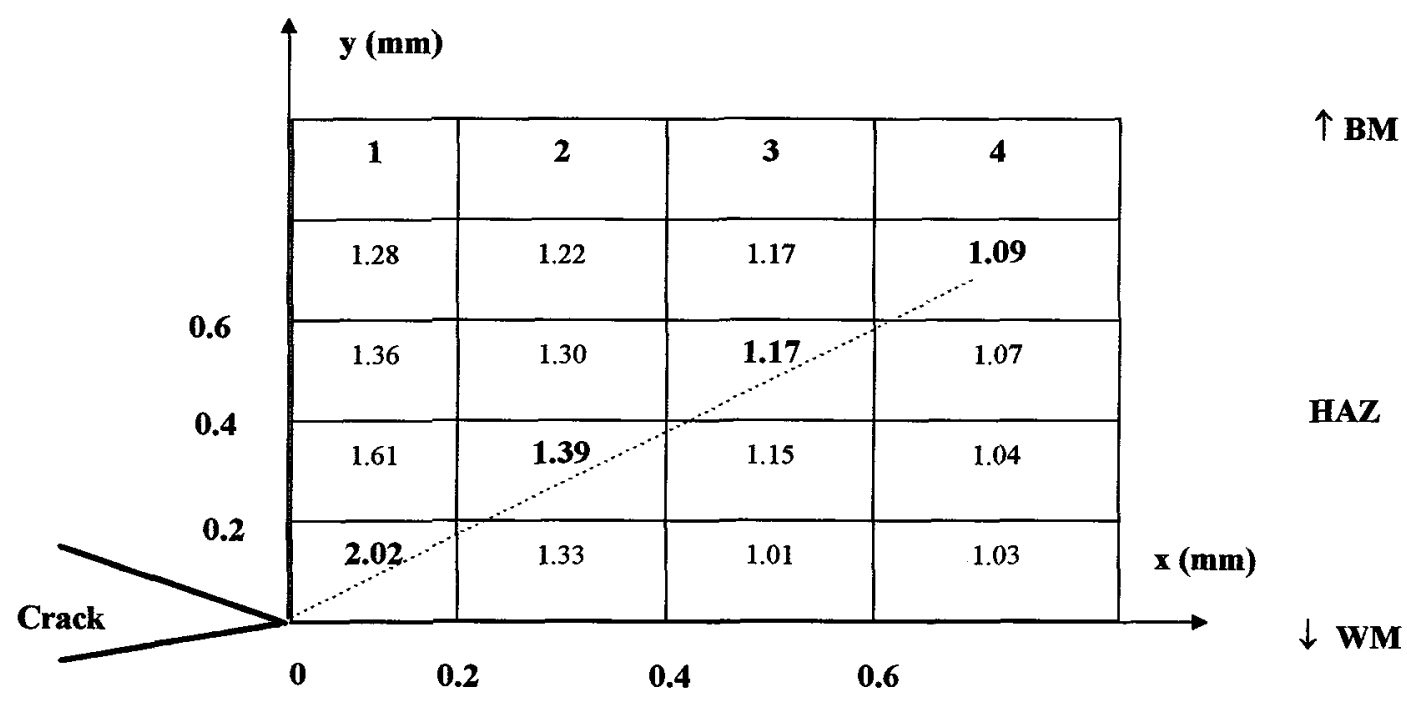

Figure 7 : distribution of $R / R_{0}$ around the crack tip. for the trimetallic specimen.

(displacement value $: 2 \mathrm{~mm}$ )

\section{CONCLUSION}

Considering the evolution of the void growth parameter for the three configurations it must be emphasized that :

- In a situation of over-matching, the bimetallic specimen seems the most harmful because of the yielding process which develops essentially in the softer material.

- Benefical effects of the HAZ have also been highlighted and adopting the softer material properties to characterize fracture of over-matched welded joints seems therefore to be a conservative approach.

A crack extension analysis based upon a critical value of the void growth parameter seems to be an interesting approach. Ours results need complementary investigations in order to confirm the meshing refinement effects on the crack extension estimation.

In the case of the trimetallic specimen, when analysing the void growth rate distribution around the crack tip, as a deviation of the crack from its initial plane is expected, a crack extension analysis is more difficult, since it requires a complete re-meshing after each step of crack extension.

\section{REFERENCES}

[1] BUI H.D. and DANG VAN K., "Some recently-developed analytical aspects of fracture mechanics ", Nuclear Engng. and Design, 105, pp. 3-9, (1987)

[2] HEUSER A., TWICKLER R., DAHL W., « Experimental investigations of the failure behaviour of welded joints and its numerical simulation by using elastic-plastic finite element calcualtions", The 
Fracture Mechanics of Welds, EGF Pub. 2 (edited by J.G. BLAUEL and K.H. SCHWALBE), MEP, London, pp. 97-124, (1987).

[3] ERIPRET C., IGNACCOLO S., GILLES P., « Study of mechanical behaviour and fracture resistance of welded joints ", Revue de Métallurgie, pp. 214-225, Février (1995).

[4] ROUSSELIER G., " Les modèles de rupture ductile et leurs possibilités actuelles dans le cadre de l'approche locale de la rupture " International Seminar on Local Approach of Fracture, Moret-Sur-Loing , France, pp. 257-284, (Juin 1986).

[5] RICE J.R. and TRACEY D.M., “On the ductile enlargement of voids in triaxial stress fields”, J. Mech. Phys. Solids, 17, pp. 201-217, (1969).

[6] DEVAUX J.C., MOTTET G., BALLADON P., PELlisSIER-TANON A., "Calibrationon the parameters of ductile fracture damage model o an austenitic-ferritic duplex welded joint ", Nuclear Engng. and Design 105, pp. 131-138, (1987).

[7] DELMOTTE J., « Modélisation numérique de la déchirure ductile en milieu bidimensionnel à l'aide d'une approche locale », Thèse, Université de Technoloqie de Compiègne, (1992).

[8] AL RASSIS A., "Contribution à l'étude de la déchirure ductile à chaud dans les joints soudés et modélisation numérique en approche globale et locale ", thèse de doctorat, Université de Lille I, déc. 1995. [9] SYSTUS, "Manuel d'utilisation de la mécanique de la rupture", Framasoft, édition 1994.

[10] AL RASSIS A., IMAD A., NAIT ABDELAZIZ M., MESMACQUE G., AMROUCHE A., ERIPRET C. : «Etude de la résistance à la déchirure ductile des joints soudés : modélisation numérique ». $2^{\text {ème }}$ Congrès de Mécanique, vol. 2, pp. 16-21, Avril 1995, Casablanca (Maroc)..

[11] AL RASSIS A., IMAD A., NAIT ABDELAZIZ M., MESMACQUE G., AMROUCHE A., ERIPRET C. : "A numerical analysis of the ductile tearing in mis-matched welded joints.$^{\text {nd }}$ International Symposium on Mis-Matching of Welds, April 24-26, Germany.

[12] DODDS R.H., TANG JR. and M., "Numerical procedures to model ductile crack extension ", Engng. fract. Mech., Vol. 46, N 2, pp. 253-264, (1993).

[13] XIN X.J. and GOLDTHORPE M.R., « Finite element analysis of stable crack growth in three sizes of compact specimens of A508 steel », Fatigue and Fract. of Engng. Mat. and struct., 12, vol. 16, pp. 1309$1327,(1993)$.

[14] BIBLY B.A., HOWARD I.C. and LI Z.H., « Mesh independent cell models for continuum damage theory ", Fatigue and fract. Engng. Mater. and Struct., Vol. 17, $N^{\circ} 10$, pp. 1221-1233, (19994)

[15] ASTM standard, "Standard test of $J_{1 c}$, a measure of fracture toughness".E 813-89. 